\title{
Determinasi Financial dan Non Financial Faktor terhadap Keputusan Opini Audit Modifikasi Going Concern (Prediksi Kebangkrutan Perusahaan yang Terdaftar di Bursa Efek Indonesia)
}

\author{
Indra Saputra \\ Magister Akuntansi Fakultas Ekonomi dan Bisnis Universitas Trisakti \\ indrasp88@gmail.com
}

\begin{abstract}
The purpose of this study is to examine the financial and non-financial factors of the auditor's decision to provide an audit opinion modification that will be carried out as a consideration of the company's bankruptcy. This study uses panel data consisting of secondary data, namely the company's annual report for 2013-2016. The data was obtained by accessing the website www.idx.co.id and Indonesia Capital Market Directory (ICMD). This test is carried out using logistic regression analysis. The results of financial factors research in model (i) show that financial difficulties negatively affect going-concern opinion audit decisions, comprehensive income and company cash flows show no significant positive effect on going-concern modification audit opinion decisions. While the non-financial factors in model (II) Audit ownership and auditor's assessment do not significantly influence the decision to grant a modified audit opinion. Whereas audit fees and previous audit opinions have a significant positive effect on going concern audit opinion audit decisions. And the company proved positively insignificant towards going concern audit audit decisions.
\end{abstract}

\section{Keywords: Modified Opinion Audit Going concern, Financial distress, Comprehensive Income, Audit.}

Abstrak. Tujuan penelitian ini adalah untuk menguji faktor financial dan non financial terhadap keputusan auditor dalam memberikan opini audit modifikasi going concern yang dijadikan sebagai prediksi kebangkrutan perusahaan. Penelitian ini menggunakan data data panel secara kuantitatif berupa data sekunder yaitu laporan tahunan perusahaan selama 2013-2016. Data tersebut diperoleh dengan cara mengakses website www.idx.co.id dan Indonesia Capital Market Directory (ICMD). Pengujian ini dilakukan dengan menggunakan analisis regresi logistik. Hasil penelitian faktor financial dalam model (i) menunjukkan financial distress berpengaruh negatif signifikan terhadap keputusan pemberian opini audit modifikasi going concern, comprehensive income dan cash flow perusahaan berpengaruh positif tidak signifikan terhadap keputusan pemberian opini audit modifikasi going concern. Sedangkan faktor non financial dalam model (II) Audit tenure dan reputasi auditor berpengaruh negatif tidak signifikan terhadap keputusan pemberian opini audit modifikasi going concern. Sedangkan audit fee dan opini audit sebelumnya berpengaruh positif signifikan terhadap keputusan pemberian opini audit modifikasi going concern. Dan umur perusahaan berpengaruh positif tidak signifikan terhadap keputusan pemberian opini audit modifikasi going concern.

Kata kunci: Opini Audit modifikasi Going concern, Financial distress, Comprehensive Income, Audit. 



\section{A. Pendahuluan}

Dalam memprediksi kelangsungan hidup suatu perusahaan, auditor seringkali mengalami dilema antara moral dan etika. Hal ini disebabkan karena adanya hipotesis self fullfilling prophecy. Self fullfilling prophecy adalah suatu kondisi dimana auditor eksternal mengalami keraguan atas operasional perusahaan (Louwers, et.al, 2011). Jika auditor memberikan opini going concern, maka Perusahaan akan lebih cepat bangkrut karena banyak investor yang menarik dananya (Venuti, 2007). Penyebab lain adalah hampir tidak ada suatu panduan yang jelas atau penelitian yang dapat dijadikan acuan pemilihan tipe opini going concern yang harus dipilih (LaSalle dan Asokan, 1996) karena pemberian opini going concern bukanlah suatu tugas yang mudah (Koh dan Tan, 1999). Di Indonesia isu mengenai going concern telah berkembang sejak lama yaitu dimulai pada tahun 1997, sebanyak empat belas perusahaan yang memperoleh opini wajar tanpa pengecualian bangkrut pada tahun berikutnya. Pada tahun 1998, limabelas perusahaan yang juga memperoleh opini audit yang sama juga bangkrut pada tahun berikutnya. Opini audit menjadi isu yang penting bagi publik khususnya para stakeholders. Kegagalan auditor untuk memberikan opini yang tepat telah membuat publik dan para stakeholders mempertanyakan independensi auditor dalam memberikan penilaian dan opini audit. Panduan untuk mempertimbangkan opini dalam hal auditor menghadapi masalah kesangsian atas kemampuan entitas dalam mempertahankan kelangsungan hidup diatur dalam Standar Audit (SA) yang dirancang oleh Institut Akuntan Publik Indonesia (IAPI). Berdasarkan SA 570, apabila auditor menyimpulkan adanya kesangsian substansial mengenai kemampuan perusahaan untuk melanjutkan usahanya, auditor harus memberikan opini audit dengan going concern(IAPI, 2014).

Kondisi keuangan perusahaan merupakan gambaran atas kinerja dari perusahaan. Kondisi keuangan perusahaan merupakan salah satu hal penting dalam pengambilan keputusan dalam mempertahankan perusahaan. Penelitian yang dilakukan Gallizo dan Saladrigues (2016) dan Wertheim dan Robinson (2011) menemukan bahwa hubungan financial distress dan probabilitas untuk penerimaan opini audit going concern adalah negatif. Sementara Tagesson dan Öhman (2015) menemukan bahwa financial distress berhubungan positif dengan kemungkinan untuk dikeluarkannya opini audit going concern. Perusahaan yang memiliki ROA negatif dalam periode yang berurutan akan memicu masalah going concern karena ROA yang negatif artinya bahwa perusahaan tersebut mengalami kerugian dan ini akan mengganggu kelangsungan hidup perusahaan tersebut. Beberapa peneliti seperti Kida (1980), Mutchler J. F (1985), Menon dan Kenneth (1987), Koh dan Larry (1990), Hani et.al (2003) dan Lee dan Asokan (2005), menemukan bahwa rasio profitabilitas berpengaruh terhadap pemberian opini going concern.

Arus kas (cash flow) merupakan faktor utama yang harus dipertimbangkan oleh auditor dalam menilai kemampuan perusahaan. Semakin tinggi penjualan, maka semakin tinggi kas yang dihasilkan dari aktivitas operasional perusahaan. Pertumbuhan Perusahaan (growth) dapat ditunjukkan dengan peningkatan laba operasi (profit) yang semakin meningkat dari periode ke periode. Semakin tinggi tingkat pertumbuhan perusahaan, maka semakin kecil kemungkinan auditor menerbitkan opini going concern. Salah satu faktor yang berpengaruh dalam keputusan auditor untuk memberikan opini audit going concern adalah ukuran perusahaan. Dalam penelitiannya Gallizo et al. (2016) menemukan bahwa ukuran perusahaan yang semakin besar maka 

perusahaan dapat menjamin kelangsungan usahanya. Oleh karena itu, semakin kecil ukuran sebuah perusahaan maka probabilitas perusahaan tersebut untuk menerima opini audit going concern menjadi semakin besar. Audit tenure adalah lamanya hubungan auditor dan klien yang diukur dengan jumlah tahun (Junaidi, Hartono, \& Jogiyanto, 2010). Lamanya perikatan auditor dengan auditee yang sama akan mempengaruhi independensi auditor. Masalah independensi tersebut terkait dengan keraguan auditor untuk menyatakan opini audit going concern. Junaidi et al.(2010) menyebutkan bahwa audit tenure memiliki pengaruh secara signifikan terhadap penerimaan opini audit going concern.

Dalam penelitian Junaidi et al.(2010) ditemukan pengaruh antara reputasi KAP terhadap opini audit going concern. KAP yang berafiliasi dengan KAP besar dunia cenderung memberikan opini audit going concern terhadap auditee yang menghadapi masalah kelangsungan usaha dibandingkan dengan KAP yang tidak berafiliasi dengan KAP besar dunia. Penelitian yang dilakukan oleh Herry Susanto dan Nur Mettani Aquariza (2013) yang meneliti dampak opini audit, kualitas audit, likuiditas, profitabilitas dan solvabilitas terhadap opini going concern.menunjukkan bahwa opini audit dan solvabilitas berpengaruh positif terhadap opini going concern. Sedangkan kualitas auditor, profitabilitas dan likuiditas tidak berpengaruh terhadap opini going concern. Nasser dan Wahid (2006) terhadap perusahaan-perusahaan yang terdaftar di Kuala Lumpur Stock Exchange menunjukan perusahaan-perusahaan besar yang memiliki masalah keuangan juga cenderung untuk melakukan pergantian auditor.Indikasi kebangkrutan dapat dilihat dari apakah perusahaan mengalami kesulitan keuangan (financial distress). Platt et al. (2002) menjelaskan financial distress sebagai tahapan penurunan kondisi keuangan yang terjadi sebelum terjadinya kebangkrutan ataupun likuidiasi. Kondisi financial distress tergambar dari ketidakmampuan perusahaan atau tidak tersedianya suatu dana untuk membayar kewajiban yang telah jatuh tempo. Dalam memberikan opini, auditor harus mempertimbangkan kelangsungan usaha bisnis klien setidaknya selama satu periode kedepan (Arens \& Loebbecke, 1997). Penelitian Gallizo et al.(2016) menemukan bahwa financial distress, mempunyai pengaruh negatif terhadap opini audit going concern. Sementara Tagesson et al. (2015) mengungkapkan terdapat pengaruh positif financial distress terhadap opini audit going concern.

Gallizo et al.(2016) menemukan bahwa ukuran perusahaan berpengaruh negatif terhadap opini audit going concern. Junaidi et al.(2010) menemukan bahwa semakin lama KAP melakukan perikatan audit dengan klien yang sama cenderung menimbulkan keraguan bagi auditor untuk memberikan opini going concern.penelitian yang dilakukan oleh Tagesson et al.(2015), Junaidi et al. (2010) dan Nasser et al.(2006) mengungkapkan terdapat pengaruh antara reputasi auditor dengan pemberian opini audit going concern. Berdasarkan latar belakang tersebut peneliti termotivasi untuk meneliti lebih lanjut faktor-faktor apa saja yang mempengaruhi keputusan pemberian opini audit going concern pada perusahaan yang terdaftar di Bursa Efek Indonesia karena beberapa tahun terakhir banyaknya perusahaan yang mengalami kebangkrutan atau kesulitan keuangan yang merupakan dampak dari terjadinya krisis global dimana perusahaan tidak mampu mempertahankan kelangsungan usahanya (going concern). Adapun tujuan penelitian ini adalah untuk menguji secara empiris mengenai Pengaruh faktor financial dan faktor non financial terhadap keputusan pemberian opini going concern pada perusahaan yang terdaftar di Bursa Efek Indonesia periode 2013-2016 sehingga penelitian ini dapat memberikan kontribusi baik secara teoritis maupun praktisi 

terutama auditor diharapkan dapat memberikan masukkan dalam memberikan penilaian kepada Perusahaan mengenai keputusan pemberian opini audit going concern yang mengacu kepada kelangsungan hidup perusahaan. Sedangkan bagi investor diharapkan dapat memberikan masukkan bagi investor yang ingin berinvestasi, agar memiliki bahan pertimbangan dalam menetapkan keputusan berinvestas begitu juga bagi manajemen perusahaan, diharapkan dapat memberikan masukkan bagi manajemen dalam mengelola usahanya dengan baik dan mengenali faktor-faktor yang berpotensi menimbulkan opini auditor tentang going concern sehingga dalam jangka panjang usahanya dapat bertahan dan menurunkan kemungkinan opini auditor tentang going concern.

\section{B. Landasan Teori}

Teori Keagenan(Agency Theory)

Teori keagenan (agency theory) merupakan teori yang mendasari praktik bisnis perusahaan yang dipakai saat ini. Teori ini merupakan konsep yang menjelaskan hubungan kontraktual antara principals dan agent. Jensen dan Meckling (1976) menyatakan bahwa hubungan keagenan merupakan suatu kontrak dimana principal dalam hal ini pemegang saham (shareholder) mendelegasikan pertanggungjawaban atas decision making atau tugas tertentu kepada agen (manajer) sesuai dengan kontrak yang telah disepakati. Inti dari agency theory adalah pendesainan kontrak yang tepat untuk menyelaraskan kepentingan principal dan agen dalam hal terjadi konflik kepentingan (Scott, 2014). Dalam kaitan antara teori agensi dengan pemberian opini going concern, agen bertugas dalam menjalankan perusahaan dan menghasilkan laporan keuangan sebagai bentuk dari pertanggungjawaban manajemen.

\section{Teori Sinyal(Signalling Theory)}

Teori sinyal menjelaskan bahwa pemberian sinyal yang diberikan oleh manajemen perusahaan akan dapat mengurangi asimetri informasi. Manajemen perusahaan dapat memberikan informasi berupa laporan tahunan dimana laporan tahunan tersebut tidak hanya berupa informasi keuangan, tetapi juga informasi nonkeuangan. Laporan keuangan yang dipublikasikan diharapkan dapat membantu para pengguna laporan keuangan, terutama para kreditor dan investor dalam mengambil keputusan kredit dan investasi. Menurut Jama'an(2008), adanya sinyal opini bebas yang diberikan oleh KAP merupakan sinyal yang mencerminkan keandalan informasi yang dihasilkan oleh perusahaan yang telah diaudit. Salah satu opini yang diberikan oleh auditor independen kepada auditee adalah opini going concern dimana auditor memiliki kesangsian atas kelangsungan hidup auditee.

\section{Going concern dan Opini Audit Going concern}

Menurut Belkaoui (2012) going concern adalah suatu dalil yang menyatakan bahwa suatu entitas akan menjalankan terus operasinya dalam jangka waktu yang cukup lama untuk mewujudkan proyeknya, tanggungjawab serta aktivitas-aktivitasnya yang tiada henti. Dalil ini memberikan gambaran bahwa suatu entitas diharapkan akan terus beroperasi dalam jangka waktu yang tidak terbatas atau tidak diarahkan menuju arah likuidasi. Opini audit going concern merupakan opini yang dikeluarkan oleh auditor untuk memastikan apakah perusahaan dapat mempertahankan kelangsungan hidupnya (SPAP, 2011). 



\section{Financial Faktor}

Pengaruh Financial Distress terhadap keputusan pemberian Opini Going Concern

Dalam memberikan opini audit, sesuai dengan standar audit yang berlaku auditor harus memastikan tidak ada kesangsian substansial mengenai kemampuan usaha perusahaan untuk melanjutkan usahanya. Kemampuan entitas dalam mempertahankan kelangsungan usahanya tercermin dari kondisi kesehatan keuangannya.Auditor harus mengetahui apakah perusahaan tersebut memiliki kesulitan keuangan (financial distress). Dengan tingkat kesulitan keuangan yang rendah artinya nilai z score semakin tinggi menunjukan perusahaan memiliki kondisi keuangan yang baik, sehingga probabilitas perusahaan menerima opini audit going concern adalah kecil. sehingga hipotesis yang diajukan dalam penelitian ini adalah:

H1 : Financial Distress berpengaruh positif signifikan terhadap Opini Audit Going Concern.

Pengaruh comprehensive income terhadap keputusan pemberian Opini Going Concern

Laba komprehensif adalah total total perubahan aktiva bersih (ekuitas) perusahaan selama satu periode, yang berasal dari semua transaksi dan kegiatan lain dari sumber lain atau dari pemilik. Semakin besar nilai yang tercatat pada laba rugi komprehensif maka semakin kecil kemungkinan pemberian opini audit going concern dengan pertimbangan bahwa penentuan nilai tersebut cukup besar untuk mempengaruhi kinerja perusahaan. Sehingga hipotesis yang diajukan dalam penelitian ini adalah:

H2: Comprehensive Income berpengaruh negatif signifikan terhadap keputusan pemberian opini going concern

\section{Pengaruh Cash Flow terhadap keputusan pemberian Opini Going Concern}

Salah satu rasio arus kas yang dapat digunakan oleh auditor untuk menilai kemampuan perusahaan dalam melanjutkan usahanya adalah cash flow operation to total debt ratio. Perusahaan dengan tingkat penjualan yang tinggi, maka semakin tinggi pula kas yang dihasilkan dari aktivitas operasi perusahaan. Dengan demikian semakin besar kemungkinan perusahaan dapat memenuhi pembayaran hutang-hutangnya setiap tahun, sehingga semakin kecil kemungkinan auditor menerbitkan opini going concern.sehingga hipotesis yang diajukan dalam penelitian ini adalah:

H3 : Arus kas berpengaruh positif signifikan terhadap keputusan pemberian Opini Going Concern

\section{Non Financial Faktor}

Pengaruh Audit Tenur terhadap keputusan pemberian Opini Going Concern

Audit tenure merupakan jumlah tahun dimana KAP melakukan perikatan audit dengan klien yang sama. Ketika KAP mempunyai jangka waktu hubungan yang lam adengan kliennya, maka mendorong pemahaman yang lebih baik atas klien sehingga auditor dapat menjadi lebih sensitif berkaitan dengan isu going concern perusahaan. Namun, semakin lama hubungan auditor dengan klien dikhawatirkan independensi auditor menjadi semakin berkurang dan berpengaruh terhadap pemberian opini audit. sehingga hipotesis yang diajukan dalam penelitian ini adalah:

H4 : Audit Tenure perusahaan berpengaruh negatif signifikan terhadap keputusan pemberian Opini Going Concern 



\section{Pengaruh Reputasi KAP terhadap keputusan pemberian Opini Going Concern}

Reputasi auditor menunjukan prestasi dan kepercayaan publik yang disandang auditor atas nama besar yang dimiliki auditor tersebut.Auditor yang bereputasi baik cenderung akan menerbitkan opini audit going concernjika pada perusahaan klien terdapat masalah-masalah yang berkaitan dengan keberlangsungan usaha klien. Sehingga hipotesis yang diajukan dalam penelitian ini adalah:

H5 : Reputasi Auditor berpengaruh negatif signifikan terhadap keputusan pemberian opini audit Going Concern.

\section{Pengaruh Fee Audit terhadap keputusan pemberian Opini Going Concern}

Fee audit merupakan pendapatan yang besarnya bervariasi karena tergantung dari beberapa faktor dalam penugasan audit seperti, ukuran perusahaan klien, kompleksitas jasa audit yang dihadapi auditor, risiko audit yang dihadapi auditor dari klien serta nama Kantor Akuntan Publik yang melakukan jasa audit.dalam menjalankan keahliannya, auditor harus independen, tidak memihak pada kliennya dan dalam melaporkan atau mendeteksi kecurangan harus bebas dari pengaruh fee yang diterima, namun kenyataannya sering terjadi dilema antara audit fee dengan keputusan auditor, semakin besar fee yang diterima maka semakin besar auditor mengalami kesulitan dalam memberikan keputusan opini going concern yang akan di terbitkan oleh auditor karena kecenderungan auditee mempengaruhi agar tidak independen, sehinggahipotesis yang diajukan dalam penelitian ini adalah:

H6 : Audit Fee berpengaruh positif signifikan terhadap keputusan pemberian opini audit Going Concern.

\section{Pengaruh Opini Audit tahun Sebelumnya terhadap keputusan pemberian Opini Going Concern}

Auditee yang menerima opini audit going concern pada tahun sebelumnya akan dianggap memiliki masalah kelangsungan hidupnya, sehingga semakin besar kemungkinan bagi auditor untuk mengeluarkan opini audit going concern pada tahun berjalan.Sehingga hipotesis yang diajukan dalam penelitian ini adalah:

H7 : Opini audit tahun sebelumnya berpengaruh positif signifikan terhadap keputusan pemberian Opini Going Concern.

Pengaruh Umur Perusahaan terhadap keputusan pemberian Opini Going Concern

Umur perusahaan adalah lamanya sebuah perusahaan berdiri, berkembang dan bertahan. Umur perusahaan dihitung sejak perusahaan tersebut berdiri berdasarkan akta pendirian sampai penelitian dilakukan. Hubungannya dengan going concern adalah perusahaan yang telah lama berdiri tentunya mempunyai strategi dan kiat-kiat yang lebih solid untuk tetap bisa survive dimasa depan sehingga kemungkinan perusahaan mendapatkan opini going concerna adalah kecil. Maka hipotesis yang diajukan dalam penelitian ini adalah:

H8 :Umur Perusahaan berpengaruh negatif signifikan terhadap keputusan pemberian Opini Going Concern

\section{Metode Penelitian}

Rancangan Penelitian

Penelitian ini menggunakan jenis data kuantitatif berupa data sekunder yaitu 

laporan tahunan perusahaan selama 2013-2016. Data tersebut diperoleh dengan cara mengakses website www.idx.co.id dan Indonesia Capital Market Directory (ICMD). Terdapat dua jenis variabel dalam penelitian ini, yaitu: variabel independen meliputi Financial faktor (financial distress, likuiditas, profitabilitas, arus kas dan growth) dan non financial faktor (audit tenur, reputasi KAP, audit fee, opini audit sebelumnya dan umur perusahaan) sedangkan variabel dependen yaitu opini going concern. Dalam penelitian ini, penulis melakukan pengujian hubungan sebab akibat (kausal) atas faktorfaktor yang berupa variabel independen terhadap variabel dependen yaitu opini audit going concern. Metode pengumpulan data yang digunakan dalam penelitian ini adalah data panel (pooled cross sectional). Data panel (pooled cross sectional) adalah kombinasi dari data time series (antar waktu) dengan data cross section (antar individu). Data panel akan menghasilkan data yang bersifat informatif dan lebih bervariasi (Ghozali, 2011).

\section{Operasional Variabel dan Pengukurannya Variabel Dependen (Y)}

Variabel dependen adalah tipe variabel yang dijelaskan atau dipengaruhi oleh variabel independen. Pada penelitian ini, opini going concern diukur dengan menggunakan variabel dummy, dimana ketika perusahaan menerima opini audit going concern akan diberi nilai 1 dan perusahaan yang mendapatkan opini audit non-going concern diberi nilai 0 .

\section{Variabel Independen $(\mathbf{X})$}

Variabel independen adalah variabel yang mempengaruhi variabel dependen. Dalam penelitian ini variabel independen terdiri dari :

\section{Financial Distress(X1)}

Financial distress merupakan kondisi dimana perusahaan mengalami kesulitan keuangan yang dapat diukur dengan menggunakan model Altman Z-Score (Gallizo \& Saladrigues, 2016). Data yang digunakan untuk perhitungan didapatkan dari laporan keuangan perusahaan. Model yang akan digunakan adalah Model Altman's Zscore(1968):

$$
\mathrm{Z}-\mathrm{Score}=.012 \mathrm{X}_{1}+.014 \mathrm{X}_{2}+.033 \mathrm{X}_{3}+.006 \mathrm{X}_{4}+.999 \mathrm{X}_{5}
$$

$\mathbf{X}_{\mathbf{1}}$ :Working Capital / Total Assets, $\mathbf{X}_{\mathbf{2}}=$ Retained Earnings / Total Assets, $\mathbf{X}_{\mathbf{3}}$ $=$ EBIT $/$ Total Assets, $\mathbf{X}_{\mathbf{4}}=$ Market Value of Equity /Total Liabilities, $\mathbf{X}_{\mathbf{5}}=$ Net Sales / Total Sales

Jika Z-Score< 1,81, maka kondisi kesehatan keuangan perusahaan akan digolongkan kedalam kategori distress. Jika Z-Score berada dalam rentang nilai diantara 1,81 hingga 2,99, maka kondisi kesehatan keuangan perusahaan akan digolongkan kedalam kategori indifference. Jika Z-Score> 2.99, maka kondisi kesehatan keuangan perusahaan akan digolongkan kedalam kategori non-distress.

\section{Comprehensive Income $\left(\mathrm{X}_{2}\right)$}

Comprehensive Income merupkan salah satu elemen statement keuangan. Laba komprehensif merupakan perubahan ekuitas selama periode yang berasal dari sumber- 

sumber non pemilik. Dalam penelitian ini comprehensive income di ukur dengan total laba comprehensive yang dihasilkan oleh perusahaan.

\section{Cash Flow (X3)}

Arus kas mengacu kepada kemampuan perusahaan dalam menghasilkan kas dan setara kas yang diperoleh dari aktivitas operasi, investasi dan pendanaan yang digunakan untuk membayar seluruh hutang perusahaan. Dalam penelitian ini, arus kas diukur dengan mengunakan operating cash flow (OCF) yaitu total arus kas operasi dibagi dengan total liabilitas

\section{Audit Tenure (X4)}

Variabel audit tenure dalam penelitian ini diukur dengan menghitung tahun dimana KAP yang sama telah melakukan perikatan dengan auditee. Tahun pertama perikatan dimulai dengan angka 1 dan ditambah dengan satu untuk tahun-tahun berikutnya.

\section{Reputasi KAP (X5)}

Pada penelitian ini, reputasi auditor diproksikan dengan menggunakan ukuran KAP.Variabel reputasi auditor diukur dengan menggunakan variabel dummy. Apabila auditor berasal dari KAP yang termasuk dalam kategori The Big Four Accounting Firm, maka akan diberi kode 1 sedangkan jika tidak termasuk dalam kategori The Big Four Accounting Firm akan diberi kode 0

\section{Audit Fee (X6)}

Pada penelitian ini audit fee di ukur adalah jumlah biaya yang dikeluarkan oleh perusahaan untuk membiayai jasa audit pada tahun berjalan termasuk jasa asuurance yang diberikan oleh auditor atau dengan kata lain Total Fee $=$ audit fee ditambah dengan Non Audit Fee.

\section{Opini Audit Sebelumnya (X7)}

Pada penelitian ini, opini audit tahun sebelumnya diukur dengan menggunakan variabel dummy, dimana ketika perusahaan menerima opini audit going concern akan diberi nilai 1 dan perusahaan yang mendapatkan opini audit non-going concern diberi nilai 0 .

\section{Umur Perusahaan(X8)}

Variabel umur perusahaan dalam penelitian ini diukur dengan lamanya perusahaan beroperasi yang dihitung dengan awal tahun dimana perusahaan berdiri berdasarkan akte pendirian perusahaan sampai periode penelitian.

\section{Metode Pengumpulan Data \\ Populasi dan Sampel}

Dalam penelitian ini, yang menjadi populasi penelitian adalah semua perusahaan yang listing di BEI selama periode 2013-2016 yang terdapat pada ICMD tahun 2013-2016.Proses pengambilan sampel dalam penelitian ini menggunakan purposive sampling. Purposive sampling adalah teknik pengambilan sampel sumber data dengan pertimbangan tertentu. 



\section{Metode Analisis Data}

Langkah pertama dalam melakukan penelitian ini adalah menentukan hipotesis yang akan diteliti. Langkah selanjutnya dalam penelitian ini adalah analisis data. Metode analisis data ini diperlukan agar data hasil penelitian dapat mudah dipahami oleh pembaca. Data dalam penelitian ini akan diuji dengan uji statistik deskriptif dan uji statistik inferensial untuk pengujian hipotesis.

\section{Analisis Statistik Deskriptif}

Analisis statistik deskriptif digunakan dalam penelitian ini untuk memberikan gambaran atau informasi mengenai variabel-variabel penelitian yang diukur pada sampel. Analisis statistik deskriptif ini meliputi jumlah sampel, nilai minimum, nilai maksimum, nilai rata-rata (mean) dan standar deviasi. Data yang akan diteliti akan dikelompokkan berdasarkan opini audit yang diterimanya dalam dua kategori, yaitu auditee yang menerima opini audit going concern (GCAO) dan auditee yang menerima opini audit non-going concern (NGCAO).

\section{Uji Multikolinearitas.}

\section{Analisis Statistik Inferensial}

Analisis statistik inferensial digunakan untuk pengujian hipotesis. Pengujian hipotesis dalam penelitian ini adalah menggunakan regresi logistik berganda. Regresi logistik ini digunakan karena variabel bebas merupakan campuran antara variabel kontinyu (metric) dan kategorial (non-metric). Analisis regresi dilakukan dengan menggunakan bantuan program Statistical Package for Social Science (SPSS) 21.0 for Windows. Pengujian ini dilakukan pada tingkat signifikansi $(\alpha=5 \%)$. Model regresi logistik yang digunakan untuk menguji hipotesis penelitian ini adalah sebagai berikut:

\section{Model I}

Financial Faktor terhadap Going Concern Opinion

$$
\operatorname{Ln} \frac{G C}{1-G C}=\alpha+\beta 1 F D+\beta 2 C I+\beta 3 C F O T D+\varepsilon
$$

\section{Model II}

Non Financial Faktor terhadap Going Concern Opinion

\begin{tabular}{|l}
$\qquad n \frac{G C}{1-G C}=\alpha+\beta 1 A T+\beta 2 R E P+\beta 3 A F+\beta 4 O P S I+\beta 5 A G E+\varepsilon$ \\
$\qquad n \frac{G C}{1-G C}$ \\
$=\quad$ opini audit going concern (dummy variable, 1 untuk auditee
\end{tabular}
dengan opini audit non-going concern (NGCAO) dan 0 untuk auditee dengan opini audit going concern (GCAO).

$\alpha=$ Konstanta, $\beta=$ Koefisien masing-masing variabel, $\mathrm{FD}=$ Financial distress menggunakan $\mathrm{Z}$ score, $\mathrm{CI}=$ Comprehensive Income, $\mathrm{CFOTD}=$ Arus kas menggunakan rasio arus kas operasional dibagi dengan total Debt $(\mathrm{CFO}), \mathrm{AT}=$ Audit tenur, menggunakan lamanya perikatan audit dengan klien, REP $=$ Reputasi Auditor menggunakan variabel dummy, AF = Audit Fee, OPSI = Opini Audit tahun sebelumnya menggunakan variabel dummy, AGE = Umur Perusahaan, menggunakan lamanya perusahaan berdiri, $\varepsilon=$ Error

\section{Uji Kelayakan Model Regresi(Goodness of Fit Test)}

Langkah pertama dalam pengujian hipotesis ini adalah dengan menguji kelayakan model regresi. Uji Kelayakan model regresi dalam penelitian ini dengan Hosmer and Lemeshow's Goodness of Fit Testmenggunakan nilai Chi-Square. 

Model ini digunakan untuk menguji hipotesis nol bahwa data empiris cocok atau sesuai dengan model (tidak ada perbedaan antara model dengan data sehingga model dapat dikatakan fit).

\section{Uji Keseluruhan Model Fit (Overall Model Fit Test)}

Pengujian ini dilakukan untuk menilai apakah model yang telah dihipotesiskan telah fit atau tidak dengan data. Hipotesis yang digunakan untuk menilai model fit adalah:

$\mathrm{H}_{0}=$ Model yang dihipotesiskan fit dengan data

$\mathrm{H}_{1}=$ Model yang dihipotesiskan tidak fit dengan data

\section{Pengujian Hipotesis}

Pengujian hipotesis dengan menggunakan model regresi logistik digunakan dalam penelitian ini adalah untuk mengetahui variabel independen berpengaruh terhadap variabel dependen. Pengujian hipotesis ini dapat dilakukan dengan dua cara, yaitu

1. Pengujian Parsial (Wald Statistic)

2. Pengujian Simultan (Omnibus Test of Model Coefficient)

\section{Hasil Penelitian dan Pembahasan}

\section{Deskripsi Objek Penelitian}

Sampel yang digunakan dalam penelitian ini adalah seluruh perusahaan manufaktur yang terdaftar di BEI selama tahun 2013-2016. Berdasarkan kriteria sampel yang telah ditetapkan, proses pemilihan sampel dapat disajikan dalam tabel 1 dibawah ini :

\section{Tabel 1}

Proses Pemilihan Sampel

\begin{tabular}{ccc}
\hline No & \multicolumn{1}{c}{ Kriteria } & $\begin{array}{c}\text { Jumlah } \\
\text { Perusahaan }\end{array}$ \\
\hline 1. & $\begin{array}{l}\text { Perusahaan manufaktur yang terdaftar secara berturut-turut dan } \\
\text { mempublikasikan laporan auditan di Bursa Efek Indonesia } \\
\text { selama periode 2013-2016 }\end{array}$ & 146 \\
\hline
\end{tabular}

2. Perusahaan manufaktur yang terdaftar secara berturut-turut di BEI tetapi tidak mempublikasikan laporan auditan selama periode 2013-2016

5. Perusahaan yang tidak mengalami laba bersih negatif atau saldo laba negatif dan arus kas operasi negatif sekurangkurangnya 1 (satu) periode pengamatan selama tahun 2013 2016 Jumlah Sampel Pengamatan 30

Tahun Pengamatan 4

Jumlah Pengamatan $\quad 120$

Sumber: www.idx.co.id, data diolah, 2017

Dari sampel tersebut di atas, peneliti mengkategorikannya ke dalam dua kelompok berdasarkan jenis opini audit yang diterima oleh perusahaan, yaitu kelompok yang mendapatkan opini audit going concern (GCAO) dan kelompok yang mendapatkan opini non going concern (NGCAO). Pembagian kelompok tersebut dapat disajikan dalam tabel 2 berikut ini: 

Tabel 2

Pembagian Perusahaan Berdasarkan Opini Audit

\begin{tabular}{lrrrrr}
\hline \multirow{1}{*}{ Opini } & \multicolumn{4}{c}{ Periode } & Total \\
\cline { 2 - 5 } & $\mathbf{2 0 1 3}$ & $\mathbf{2 0 1 4}$ & $\mathbf{2 0 1 5}$ & $\mathbf{2 0 1 6}$ & \\
GCAO & 14 & 13 & 18 & $\mathbf{1 0}$ & $\mathbf{5 5}$ \\
NGCAO & 16 & 17 & 12 & $\mathbf{2 0}$ & $\mathbf{6 5}$ \\
Total & $\mathbf{3 0}$ & $\mathbf{3 0}$ & $\mathbf{3 0}$ & $\mathbf{3 0}$ & $\mathbf{1 2 0}$ \\
\hline \multicolumn{5}{c}{ Sumber $:$ data diolah dengan SPSS, 2017} &
\end{tabular}

\section{Analisis Statistik Deskriptif}

Tabel 3

Statistik Deskriptif

\begin{tabular}{lcrrrr}
\hline \multicolumn{5}{c}{ Descriptive Statistics } \\
& $\mathrm{N}$ & \multicolumn{1}{c}{ Minimum } & Maximum & \multicolumn{1}{c}{ Mean } & Std. Deviation \\
FD & 120 & -1.35 & 1.40 & .0839 & .23522 \\
Cl & 120 & -2278718.00 & 12445448.95 & 21902.9358 & 1273435.22313 \\
CFOTD & 120 & -4.13 & .92 & .0009 & .53373 \\
AT & 120 & 1.00 & 8.00 & 3.8750 & 2.33915 \\
AF & 120 & .00 & 51193.80 & 4458.1323 & 7517.65679 \\
AGE & 120 & 16.00 & 47.00 & 32.0667 & 8.65951 \\
Valid N (listwise) & 120 & & & &
\end{tabular}

Sumber : data diolah, 2017

\section{Analisis Statistik Inferensial}

Analisis statistik inferensial yang digunakan dalam penelitian ini adalah dengan menggunakan regresi logistik. Ghozali (2011: 225) menyatakan bahwa regresi logistik digunakan untuk menguji apakah probabilitas terjadinya variabel terikat (dependen) dapat diprediksi dengan variable bebasnya (independen). Teknik analisis regresi logistik tidak memerlukan asumsi normalitas data pada variabel bebasnya dan mengabaikan heterokedasitas.

\section{Uji Kelayakan Model Regresi (Goodness of Fit Test)}

Uji kelayakan model regresi dalam penelitian ini menggunakan Hosmer and Lemeshow's Goodness of Fit Test. Dari hasil pengolahan data statistik yang telah peneliti lakukan, maka diperoleh tabel pengujian Hosmer and Lemeshow's Goodness of Fit Test adalah sebagai berikut :

\section{Tabel 4}

Hasil Uji Hosmer and Lemeshow's Goodness of Fit Test Model I

Hosmer and Lemeshow Test

\begin{tabular}{|l|r|r|r|}
\hline Step & Chi-square & Df & \multicolumn{1}{c|}{ Sig. } \\
\hline 1 & 19.694 & & 8 \\
\hline
\end{tabular}





\begin{tabular}{l} 
Model II \\
\begin{tabular}{|l|l|r|r|}
\hline Step & Chi-square & Df & Sig. \\
\hline 1 & 2.047 & 8 & .980 \\
\hline
\end{tabular} \\
\hline
\end{tabular}

Berdasarkan tabel diatas nilai statistik Hosmer and Lemeshow's Goodness of Fit Test tabel dapat diketahui dengan melihat nilai chi-asquare yaitu sebesar 19,694 dengan probabilitas signifikansi sebesar 0,12 dan Model II nilai chi-asquare yaitu sebesar 2,047 dengan probabilitas signifikansi sebesar 0,980 dimana nilainya jauh di atas 0,05. Dengan demikian dapat disimpulkan bahwa $\mathrm{H}_{0}$ diterima, artinya model mampu memprediksi nilai observasinya atau dapat dikatakan model dapat diterima karena cocok (fit) dengan data observasinya sehingga data tersebut layak untuk digunakan dalam analisis selanjutnya.

\section{Uji Keseluruhan Model Fit (Overall Model Fit Test)}

Uji keseluruhan model fit dalam penelitian ini dilakukan dengan cara membandingkan nilai antara -2 Log Likehood (-2LL) pada awal (Block Number $=0$ ) dimana model hanya memasukkan konstanta dengan nilai -2 Log Likehood $(-2 L L)$ pada akhir (Block Number $=1)$. Adanya pengurangan nilai $-2 L L$ awal (initial $2 L L$ function) dengan nilai $-2 L L$ pada langkah berikutnya (-2LL akhir) menunjukkan bahwa model yang dihipotesiskan fit dengan data (Ghozali, 2005). Hasil uji keseluruhan model fit (Overall Model Fit Test) disajikan dalam tabel 5.

\section{Tabel 5}

Pengujian -2LL Block 1 Model I

Iteration History,a,b,c,d

\begin{tabular}{|ll|r|r|c|c|r|}
\hline & & & \multicolumn{4}{|c|}{ Coefficients } \\
\cline { 4 - 7 } Iteration & & -2 Log likelihood & Constant & FD & Cl & \multicolumn{1}{c|}{ CFOTD } \\
\hline Step 1 & 1 & 152.611 & .024 & -2.222 & .000 & .317 \\
& 2 & 150.407 & .089 & -3.524 & .000 & .400 \\
& 3 & 150.196 & .094 & -3.863 & .000 & .427 \\
& 4 & 150.193 & .092 & -3.871 & .000 & .430 \\
& 5 & 150.193 & .092 & -3.871 & .000 & .430 \\
\hline
\end{tabular}

a. Method: Enter

b. Constant is included in the model.

c. Initial -2 Log Likelihood: 165.521

d. Estimation terminated at iteration number 5 because parameter estimates changed by less than .001 .

\section{Model II}

Iteration History $\mathbf{a}, \mathrm{b}, \mathrm{c}, \mathrm{d}$

\begin{tabular}{|lr|r|r|r|r|r|r|r|}
\hline \multirow{2}{*}{ Iteration } & & & \multicolumn{5}{|c|}{ Coefficients } \\
\cline { 5 - 9 } & Step 1 1 & -2 Log likelihood & Constant & AT & REP & AF & OPSL & \multicolumn{1}{c|}{ AGE } \\
& 1 & 132.875 & -.551 & -.084 & -.517 & .000 & 1.671 & .005 \\
& 2 & 132.343 & -.565 & -.106 & -.650 & .000 & 1.856 & .005 \\
& 3 & 132.342 & -.564 & -.107 & -.659 & .000 & 1.866 & .005 \\
& 4 & 132.342 & -.564 & -.107 & -.659 & .000 & 1.866 & .005 \\
\hline
\end{tabular}

a. Method: Enter

b. Constant is included in the model.

c. Initial -2 Log Likelihood: 165.521

d. Estimation terminated at iteration number 4 because parameter estimates changed by less than .001 .

Sumber : data diolah dengan SPSS, 2017 

Berdasarkan tabel diatas nilai -2LL model Iawal adalah sebesar 152,611 dan setelah dimasukkan kelima variabel independen, maka nilai -2LL akhir mengalami penurunan menjadi sebesar 150,407. Dan Model II 132,875 menjadi 132,343 Penurunan nilai -2LL ini menunjukkan model regresi yang baik atau dengan kata lain model yang dihipotesiskan fit dengan data.

\section{Koefisien Determinasi}

Koefisien determinasi dalam penelitian ini dilakukan dengan melihat besarnya nilai koefisien determinasi pada model regresi yang ditunjukkan dengan nilai Nagelkerke R Square $\left(\mathrm{R}^{2}\right)$ :

Tabel 6

Hasil Uji Koefisien Determinasi Model I Model Summary

\begin{tabular}{|l|r|r|r|}
\hline Step & -2 Log likelihood & $\begin{array}{c}\text { Cox \& Snell R } \\
\text { Square }\end{array}$ & $\begin{array}{c}\text { Nagelkerke R } \\
\text { Square }\end{array}$ \\
\hline 1 & $150.193^{\mathrm{a}}$ & .120 & .160 \\
\hline
\end{tabular}

a. Estimation terminated at iteration number 5 because parameter estimates changed by less than .001 .

Hasil Uji Koefisien Determinasi Model II Model Summary

\begin{tabular}{|l|r|r|rr|}
\hline Step & -2 Log likelihood & \multicolumn{2}{|c|}{$\begin{array}{c}\text { Cox \& Snell R } \\
\text { Square }\end{array}$} & \multicolumn{2}{|c|}{$\begin{array}{c}\text { Nagelkerke R } \\
\text { Square }\end{array}$} \\
\hline 1 & $132.342^{\mathrm{a}}$ & .242 & & .323 \\
\hline
\end{tabular}

a. Estimation terminated at iteration number 4 because parameter estimates changed by less than .001 .

Sumber : data diolah dengan SPSS, 2017

Dari tabel diatas, Model I memiliki nilai Nagelkerke R Square (R2) adalah sebesar 0,323 yang berarti variabel-variabel independen yaitu, Comprehensive Income dan rus kas mampu menjelaskan variasi dari variabel dependen yaitu opini going concern adalah sebesar $16,0 \%$, sedangkan sisanya sebesar $84,0 \%$ dijelaskan oleh variabel-variabel lain di luar model penelitian. Model II memiliki nilai Nagelkerke R Square (R2) adalah sebesar 0,160 yang berarti variabel-variabel independen yaitu Audit Tenure, Reputasi Auditor, Audit fee, Opini audit sebelumnya dan umur perusahaan mampu menjelaskan variasi dari variabel dependen yaitu opini going concern adalah sebesar $32,3 \%$, sedangkan sisanya sebesar $67,7 \%$ dijelaskan oleh variabel-variabel lain di luar model penelitian.

\section{Uji Multikolinearitas}

Uji multikolinearitas bertujuan untuk menguji apakah model regresi ditemukan korelasi antar variabel independen (Ghozali, 2011). Multikolinearitas dapat terjadi jika nilai Variable Inflation Factor (VIF) lebih besar dari 10 atau nilai tolerance lebih kecil 0,10 (Hair, et.all, 2014) 

Tabel 7

Uji Multikolinearitas

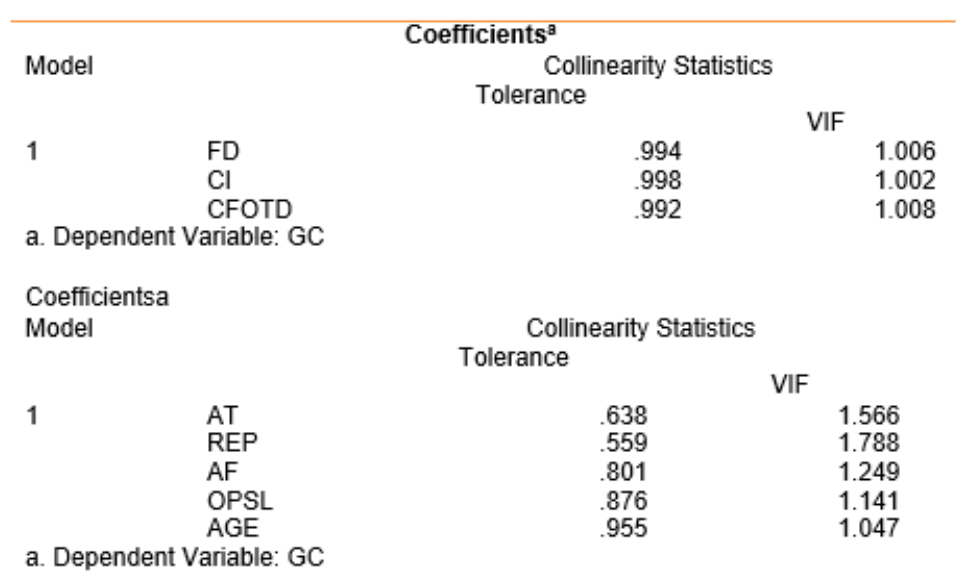

Sumber: data diolah dengan SPSS, 2017

Dari hasil tabel 7 uji multikolinearitas menunjukkan bahwa tidak ada koefisien korelasi antar variable yang lebih besar dari 10. Dengan demikian dapat disimpulkan bahwa tidak terdapat gejala multikolinearitas yang serius antar variabel bebas tersebut.

\section{Matriks Klasifikasi}

Matriks klasifikasi dalam penelitian ini digunakan untuk menunjukkan kekuatan prediksi dari model regresi untuk memprediksi probababilitas penerimaan opini going concern pada setiap perusahaan yang diteliti. Kekuatan prediksi dari model regresi ini adalah untuk memprediksi kemungkinan terjadinya variable dependen yang dinyatakan dalam persen. Hasil matriks klasifikasi ditampilkan dalam tabel 8.

\section{Tabel 8}

\section{Classification Table Prediksi Block 1}

Model I

Classification Tablea

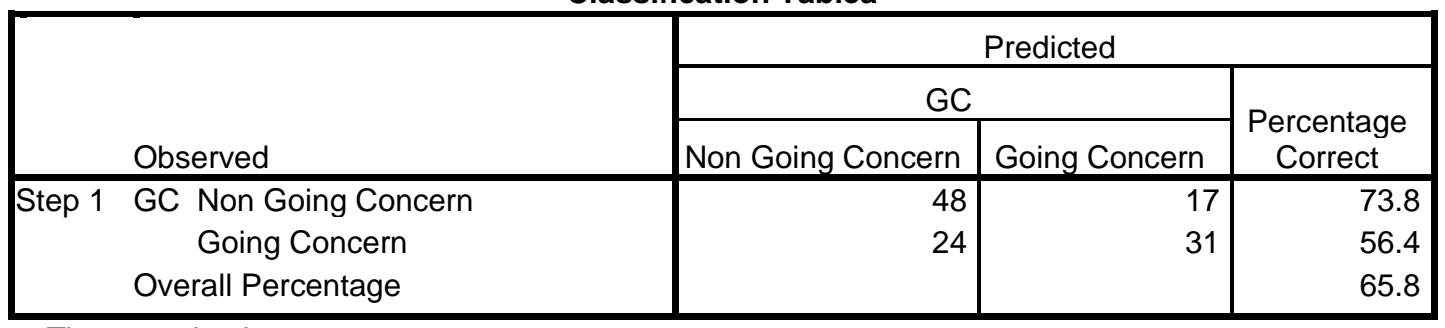

a. The cut value is .500 

Model II

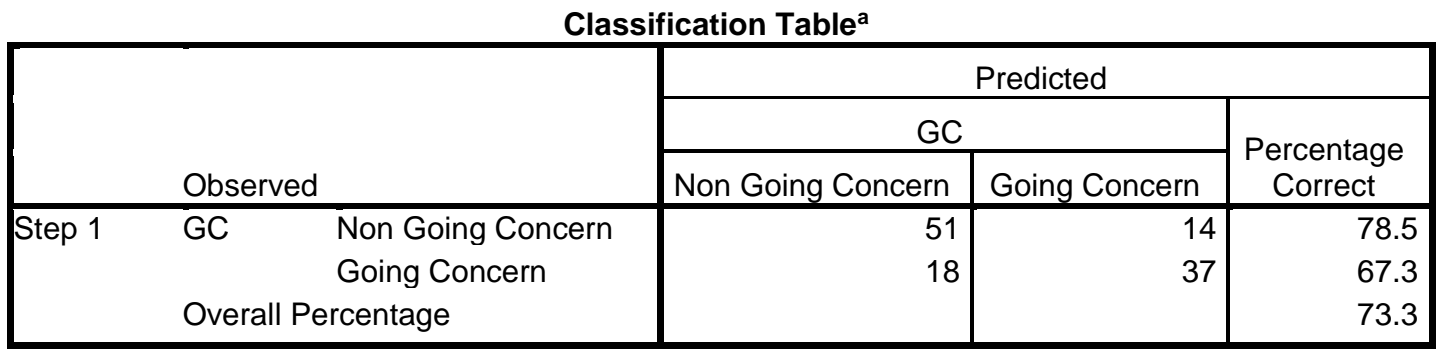

a. The cut value is .500

Sumber : data diolah dengan SPSS, 2017

Dari hasil pengujian yang ditampilkan dalam tabel 4.8 model I menunjukkan bahwa kekuatan prediksi dari model regresi untuk memprediksi kemungkinan perusahaan menerima opini audit going concern adalah sebesar 56,4\%. Hal ini menunjukkan bahwa dengan menggunakan model regresi tersebut terdapat sebanyak 31 perusahaan $(60,78 \%)$ yang diprediksi akan menerima opini going concern dari total 51 perusahaan yang memperoleh opini going concern. Kekuatan prediksi dari model regresi untuk memprediksi kemungkinan perusahaan memperoleh opini non-going concern adalah $73,8 \%$. Hal ini berarti bahwa dengan model regresi yang digunakan sebanyak 48 perusahaan $(66,67 \%)$ yang diprediksi memperoleh opini non-going concern dari total 72 perusahaan yang memperoleh opini non-going concern. Sedangkan model II menunjukkan bahwa kekuatan prediksi dari model regresi untuk memprediksi kemungkinan perusahaan menerima opini audit going concern adalah sebesar 67,3\%. Hal ini menunjukkan bahwa dengan menggunakan model regresi tersebut terdapat sebanyak 37 perusahaan $(72,54 \%)$ yang diprediksi akan menerima opini going concern dari total 51 perusahaan yang memperoleh opini going concern. Kekuatan prediksi dari model regresi untuk memprediksi kemungkinan perusahaan memperoleh opini non-going concern adalah 78,5\%. Hal ini berarti bahwa dengan model regresi yang digunakan sebanyak 51 perusahaan $(73,91 \%)$ yang diprediksi memperoleh opini non-going concern dari total 69 perusahaan yang memperoleh opini non-going concern.

\section{Analisis Regresi Logistik}

Model regresi logistik dapat dibentuk dengan melihat pada nilai estimasi parameter dalam Variables in the Equation.

\section{Tabel 9}

Hasil Pengujian Multivariate

Model I

Variables in the Equation

\begin{tabular}{|rl|r|r|r|r|r|r|}
\hline & \multicolumn{1}{|c|}{ B } & \multicolumn{1}{|c|}{ S.E. } & \multicolumn{1}{|c|}{ Wald } & \multicolumn{1}{l|}{ df } & \multicolumn{1}{l|}{ Sig. } & Exp(B) \\
\hline Step $1^{\mathrm{a}}$ & FD & -3.871 & 1.573 & 6.054 & 1 & .014 & .021 \\
& Cl & .000 & .000 & 1.773 & 1 & .183 & 1.000 \\
& CFOTD & .430 & .477 & .814 & 1 & .367 & 1.538 \\
& Constant & .092 & .235 & .153 & 1 & .696 & 1.096 \\
\hline
\end{tabular}

a. Variable(s) entered on step 1: FD, Cl, CFOTD. 



\begin{tabular}{|c|c|c|c|c|c|c|c|}
\hline \multicolumn{8}{|c|}{$\begin{array}{c}\text { Model II } \\
\text { Variables in the Equation }\end{array}$} \\
\hline & & $B$ & S.E. & Wald & df & Sig. & $\operatorname{Exp}(B)$ \\
\hline \multirow[t]{6}{*}{ Step $1^{a}$} & $\overline{\mathrm{AT}}$ & -.107 & .112 & .910 & 1 & .340 & .899 \\
\hline & REP & -.659 & .570 & 1.338 & 1 & .247 & .517 \\
\hline & AF & .000 & .000 & .184 & 1 & .668 & 1.000 \\
\hline & OPSL & 1.866 & .437 & 18.225 & 1 & .000 & 6.466 \\
\hline & AGE & .005 & .025 & .046 & 1 & .831 & 1.005 \\
\hline & Constant & -.564 & .888 & .404 & 1 & .525 & .569 \\
\hline
\end{tabular}

\section{Pengujian Hipotesis \\ Pengujian Parsial (Uji Wald)}

Pengujian ini dilakukan dengan cara membandingkan antara tingkat signifikansi

(Sig) dengan tingkat kesalahan $(\alpha)=5 \%$. Berdasarkan tabel di atas dapat diinterpretasikan sebagai berikut:

1. Pengujian hipotesis pertama $\left(\mathrm{H}_{1}\right)$

Hipotesis pertama menyatakan bahwa berarti financial distress berpengaruh negatif signifikan terhadap opini audit modifikasi going concern. Financial distress dalam penelitian ini diukur dengan Model Altman's Z-score (1968). Semakin besar nilai Z-Score yang dihasilkan maka semakin kecil kondisi financial distress yang dialami perusahaan. Kondisi financial distress pada perusahaan merupakan kondisi dimana perusahaan memiliki kecenderungan tinggi untuk bangkrut pada periode mendatang. Berdasarkan tabel diatas nilai signifikansi untuk financial distress adalah 0,014 lebih kecil dari 0,05 yang berarti $\mathrm{H} 1$ diterima financial distress berpengaruh negatif terhadap opini audit modifikasi going concern

2. Pengujian hipotesis kedua $\left(\mathrm{H}_{2}\right)$

Hipotesis kedua menyatakan bahwa Comprehensive Income (CI) berpengaruh positif signifikan terhadap keputusan pemberian opini audit going concern. Hasil pengujian menunjukkan bahwa CI probabilitas (sig.) sebesar 0,183 > 0,05. Dengan nilai signifikansi lebih besar dari 0,05 dengan pengaruh yang positif, maka dapat disimpulkan bahwa variable comprehensive income berpengaruh positif terhadap keputusan pemberian opini going concern atau dengan kata lain $\mathrm{H}_{2}$ ditolak.

3. Pengujian hipotesis ketiga $\left(\mathrm{H}_{3}\right)$

Hipotesis keempat menyatakan bahwa arus kas (CFOTD) berpengaruh positif signifikan terhadap keputusan pemberian opini audit going concern. Hasil pengujian menunjukkan bahwa nilai probabilitas (sig.) 0,367>0,05. Dengan nilai signifikansi lebih besar dari 0,05 dengan pengaruh yang positif, maka dapat disimpulkan bahwa variabel arus kas tidak berpengaruh signifikan terhadap keputusan pemberian opini audit going concern atau dengan kata lain $\mathrm{H}_{3}$ ditolak.

4. Pengujian hipotesis keempat $\left(\mathrm{H}_{4}\right)$

Hipotesis keempat menyatakan bahwa Audit Tenure (AT) berpengaruh negatif signifikan terhadap keputusan pemberian opini audit going concern. Hasil pengujian menunjukkan bahwa nilai probabilitas (sig.) $0,340>0,05$. Dengan nilai signifikansi lebih besar dari 0,05 dengan pengaruh yang negatif, maka dapat disimpulkan bahwa Audit Tenure berpengaruh negatif terhadap keputusan pemberian opini audit going concern atau dengan kata lain $\mathrm{H}_{5}$ ditolak. 

5. Pengujian hipotesis kelima $\left(\mathrm{H}_{5}\right)$

Hipotesis kelima menyatakan bahwa Reputasi Auditor (REP) berpengaruh negatiif signifikan terhadap keputusan pemberian opini audit going concern. Hasil pengujian menunjukkan bahwa nilai probabilitas (sig.) 0,247 > 0,05. Dengan nilai signifikansi lebih besar dari 0,05 dengan pengaruh yang negatif, maka dapat disimpulkan bahwa Reputasi Auditor berpengaruh negatif terhadap keputusan pemberian opini audit going concern atau dengan kata lain $\mathrm{H}_{5}$ ditolak.

6. Pengujian hipotesis keenam $\left(\mathrm{H}_{6}\right)$

Hipotesis ke enam menyatakan bahwa Audit Fee (AF) berpengaruh positif signifikan terhadap keputusan pemberian opini audit going concern. Hasil pengujian menunjukkan bahwa nilai probabilitas (sig.) 0,668 > 0,05. Dengan nilai signifikansi lebih besar dari 0,05 dengan pengaruh yang positif, maka dapat disimpulkan bahwa Audit Fee berpengaruh positif terhadap keputusan pemberian opini audit going concern atau dengan kata lain H6 ditolak.

7. Pengujian hipotesis ketujuh $\left(\mathrm{H}_{7}\right)$

Hipotesis ke tujuh menyatakan bahwa Opini Audit sebelumnya (OPSL) berpengaruh positif signifikan terhadap keputusan pemberian opini audit going concern. Berdasarkan tabel diatas nilai signifikansi untuk Audit sebelumnya (OPSL) adalah 0,00 lebih kecil dari 0,05 yang berarti H1 diterima Audit sebelumnya (OPSL) berpengaruh positif terhadap opini audit modifikasi going concern $\mathrm{H} 7$ diterima

8. Pengujian hipotesis keenam $\left(\mathrm{H}_{8}\right)$

Hipotesis ke delapan menyatakan bahwa Umur Perusahaan (AG) berpengaruh positif signifikan terhadap keputusan pemberian opini audit going concern. Hasil pengujian menunjukkan bahwa nilai probabilitas (sig.) 0,831>0,05. Dengan nilai signifikansi lebih besar dari 0,05 dengan pengaruh yang positif, maka dapat disimpulkan bahwa umur perusahaan berpengaruh positif terhadap keputusan pemberian opini audit going concern atau dengan kata lain H8 ditolak.

\section{Pengujian Simultan (Omnibus Test of Model Coefficient)}

Pengujian ini dilakukan untuk menguji apakah variabel-variabel independen secara serentak berpengaruh terhadap variable dependennya. Jika pengujian Omnibus Test of Model Coefficient menunjukkan hasil yang signifikan, maka secara keseluruhan variabel independen dimasukkan dalam model atau dengan kata lain tidak ada variable yang dikeluarkan dalam model. Jika nilai signifikansinya di bawah 0,05 , maka secara bersama-sama variabel independen berhubungan dengan variabel dependen. Hasil pengujian simultan (Omnibus Test of Model Coefficient) dapat ditunjukkan pada tabel berikut:

\section{Tabel 10 \\ Pengujian Simultan Model I}

\begin{tabular}{|c|c|c|c|c|}
\hline \multicolumn{5}{|c|}{ Omnibus Tests of Model Coefficients } \\
\hline & & Chi-square & Df & Sig. \\
\hline Step 1 & Step & 15.328 & 3 & .002 \\
\hline & Block & 15.328 & 3 & .002 \\
\hline & Model & 15.328 & 3 & .002 \\
\hline
\end{tabular}





\begin{tabular}{|c|c|c|c|c|}
\hline \multicolumn{5}{|c|}{$\begin{array}{l}\text { Pengujian Simultan Model II } \\
\text { Omnibus Tests of Model Coefficients }\end{array}$} \\
\hline & & Chi-square & $\mathrm{Df}$ & Sig. \\
\hline \multirow[t]{3}{*}{ Step 1} & Step & 33.179 & 5 & .000 \\
\hline & Block & 33.179 & 5 & .000 \\
\hline & Model & 33.179 & 5 & .000 \\
\hline
\end{tabular}

Sumber: data diolah dengan SPSS, 2017

Dari hasil pengujian yang ditampilkan dalam tabel 10 menunjukkan bahwa nilai chi-square sebesar 15,328 dan 33,179 dengan degree of freedom $=3$ dan 5 dan tingkat signifikansi sebesar 0,002 dan 0,000 lebih kecil dari $\alpha=5 \%$. Hal ini menunjukkan bahwa variabel Financial Distress, Comprehensive Income dan Arus Kas secara bersama-sama berpengaruh terhadap keputusan pemberian opini going concern. Dan model II bahwan Audit tenure, Reputasi Auditor, Audit Fee, Opini Audit sebelumnya, dan Umur perusahaan secara bersama-sama berpengaruh terhadap keputusan pemberian opini going concern.

\section{E. Kesimpulan dan Saran \\ Kesimpulan}

Berdasarkan perumusan masalah, tujuan, rerangka teoritis, pengembangan hipotesis dan hasil pengujian hipotesis yang dilakukan, maka dapat disimpulkan sebagai berikut:

\section{Model I}

1) Financial distress berpengaruh negatif signifikan terhadap keputusan pemberian opini audit going concern. Semakin tinggi nilai $\mathrm{z}$ score semakin menunjukan perusahaan memiliki kondisi keuangan yang baik, sehingga probabilitas perusahaan menerima opini audit going concern adalah kecil.

2) Comprehensive Income berpengaruh positif tidak signifikan terhadap keputusan pemberian opini audit going concern. Semakin besar nilai yang tercatat pada laba rugi komprehensif maka semakin kecil kemungkinan pemberian opini audit going concern dengan pertimbangan bahwa penentuan nilai tersebut cukup besar untuk mempengaruhi kinerja perusahaan dan sebaliknya.

3) Arus kas berpengaruh positif tidak signifikan terhadap keputusan pemberian opini audit going concern. Hal ini dapat dikatakan bahwa perusahaan yang memiliki nilai rasio kecukupan arus kas dalam hal membayar seluruh hutang-hutangnya ataupun mengalami keterlambatan dalam pembayaran utang atau bahkan dapat mengalami kegagalan pembayaran utang belum menjadi acuan auditor dalam memberikan opini audit going concern.

\section{Model II}

1) Audit tenure berpengaruh negative tidak signifikan terhadap keputusan pemberian opini audit going concern. .

2) Reputasi Auditor berpengaruh negatif tidak signifikan terhadap keputusan pemberian opini audit going concern..

3) Audit Fee berpengaruh poitif signifikan terhadap keputusan pemberian opini audit going concern..

4) Opini Audit Sebelumnya berpengaruh positif signifikan terhadap keputusan pemberian opini audit going concern Auditee yang menerima opini audit going concern pada tahun sebelumnya akan dianggap memiliki masalah kelangsungan 

hidupnya, sehingga semakin besar kemungkinan bagi auditoruntuk mengeluarkan opini audit going concern pada tahun berjalan..

5) Umur Perusahaan berpengaruh positif tidak signifikan terhadap keputusan pemberian opini audit going concern. adalah perusahaan yang telah lama berdiri tentunya mempunyai strategi dan kiat-kiat yang lebih solid untuk tetap bisa survive dimasa depan sehingga kemungkinan perusahaan mendapatkan opini going concern adalah kecil dan mendapat pertibangan khusus dari auditor.

\section{Keterbatasan}

Penelitian ini memiliki keterbatasan-keterbatasan sebagai berikut:

1) Sampel yang digunakan pada penelitian ini hanya terbatas pada perusahaan manufaktur yang terdaftar di Bursa Efek Indonesia dengan periode pengamatan tahun 2013-2016 sehingga interpretasi atas hasil penelitian hanya terbatas pada perusahaan pertambangan tersebut;

2) Penelitian ini hanya menguji dua model dengan 3 variabel keuangan dan 5 variabel non keuangan sebagai variabel independen yang dianggap mempengaruhi opini audit going concern untuk pengamatan 2013-2016 yang mana masih banyak faktorfaktor lain seperti Interaksi Auditor dan Other Comprehensif Income yang tidak diamati yang dapat mempengaruhi keputusan auditor dalam pemberian opini audit going concern;

\section{Implikasi}

1) Bagi stakeholder, diharapkan dapat memberikan informasi kepada investor tentang manfaat rasio keuangan sebagai alat untuk memprediksi kelangsungan hidup perusahaan

2) Bagi Perusahaan, diharapkan untuk mengenali perusahaannya sejak dini kondisi keuangan perusahaan, sehingga apabila terjadi permasalahan yang serius dapat dilakukan upaya penyelamatan lebih awal. Selain itu manajemen perusahaan diharapkan untuk selalu berupaya dalam mempertahankan going concern perusahaannya dan meningkatkan kinerja perusahaan;

3) Bagi auditor, diharapkan agar mampu memberikan warning kepada pembaca laporan keuangan dan mampu dalam mengidentifikasi secara tepat setiap tahapan kegagalan usaha perusahaan sehingga opini yang dihasilkan benar-benar menggambarkan kondisi keuangan perusahaan yang sesungguhnya.

4) Bagi peneliti selanjutnya disarankan : Melakukan penelitian dengan menggunakan jenis industri yang berbeda dengan rentan waktu yang lebih lama lagi dan sampel yang lebih luas, misalnya perusahaan manufaktur atau perusahaan sektor jasa sehingga dapat dilakukan perbandingan antar tiap jenis industri. Hal ini bertujuan agar kesimpulan yang dihasilkan memiliki cakupan yang lebih luas lagi. Menambahkan variabel lain dalam penelitian yang mungkin dapat mempengaruhi keputusan auditor dalam pemberian opini audit going concern, seperti audit lag, interaksi auditor dan Other comprehensive income.

\section{F. Daftar Referensi}

Arens, Alvin. A., \& Loebbecke, James K. (2011). Auditing An Integrated Approach (Seventh edition.). Upper Saddle River, New Jersey,: Prentice-Hall.Inc.

Arens, Alvin A., Randal J.Elder, \& Mark S. Beasley (2012). Auditing and Assurance Service An Integrated Approach (14 ed.). England: Pearson Educated Limited. 

Belkaoui, Ahmed Riahi. (2012). Accounting Theory: Teori Akuntansi (Fifth edition). Jakarta: Salemba Empat.

Fanny, Margaretha., \& Sylvia Saputra. (2005, September). Opini Audit Going Concern: Kajian Berdasarkan Model Prediksi Kebangkrutan, Pertumbuhan Perusahaan dan Reputasi Kantor Akuntan Publik (Studi Pada Emiten Bursa Efek Jakarta). Simposium Nasional Akuntansi VIII, 966-978.

Fargher, Neil. L., \& Liwei Jiang. (2008). Changes In The Audit Environment And Auditor's Propensity to Issue Going Concern Opinions. Auditing: A Journal of Practice \& Theory, 27 (2): 55-77.

Gallizo, J.L. dan Saladrigues, R. 2016. "An Analysis of Determinants of Going Concern Audit Opinion: Evidence from Spain Stock Exchange". OmniaScience, 12(1): 1-16.

Ghozali, Imam. (2011). Aplikasi Analisis Multivariate dengan Program SPSS. Semarang: Badan Penerbit Universitas Diponegoro.

Gujarati, D. (2003). Basic Econometric. New York: McGraw-Hill.

Hair, J., Babin, B., Anderson, R., \& C.Black, W. (2014). Multivariate Data Analysis. United States of America: Pearson Education Limited.

Hani, Cleary, \& Mukhlasin. (2003). Going Concern dan Opini Audit: Suatu Studi Pada Perusahaan Perbankan di BEJ. Simposium Nasional Akuntansi VI, 1221-1233.

Hartono, Jogiyanto. (2010). Teori Portofolio dan Analisis Investasi. Yogyakarta: BPFE.

Indonesia, Ikatan Akuntan. (2011). Standar Profesional Akuntan Publik (SPAP). Jakarta: Salemba Empat.

Ikatan Akuntan Indonesia (IAI)., 2015., Pernyataan Standar Akuntansi Keuangan. Jakarta: Salemba Empat

Jama'an. (2008). Pengaruh Mekanisme Corporate Governance, dan Kualitas Kantor Akuntan Publik Terhadap Integritas Informasi Laporan Keuangan. Tesis Tidak Dipublikasikan. Semarang: Universitas Diponegoro.

Jensen, Michael. C., dan Meckling, William H. (1976). Theory of the Firm: Managerial Behaviour, Agency Costs and Ownership Structure. Journal of Finance Economics, 3(4): 305-360.

Jensen, Michael. C., dan Meckling, William H. (1986). Agency Costs of Free Cash Flow, Corporate Finance and Takeovers. American Economics Review, 76: 305-360.

Jin, Yong Yang., dan Sang, Heon. Lee. (2013). A Study of Changes in Risk Appetite in the Stock Market and Housing Market Before and After the Global Financial Crisis in 2008 Using the vKOSPI. Modern Economy, 712-722.

Junaidi, dan Jogiyanto Hartono. (2010). Faktor Non Keuangan pada Opini Going Concern. Disampaikan pada Simposium Nasional Akuntansi XIII.

Kida, Thomas. (1980). An Investigation Into Auditors' Continuity and Related Qualification Judgement. Journal of Accounting Research, 18 (2): 506-523.

Koh, Hian Chye., dan Larry N. Killough. (1990). The Use of Multiple Discriminant Analysis In The Assesment of The Going Concern Status Of An Audit Client. Journal of Business and Accounting, 17 (2): 179-192.

dan Sen Suan Tan. (1999). A Neural Network Approach to The Prediction of Going Concern Status. Accounting and Business Research, 29 (3): 211-216. 

LaSalle, Randal E., dan Asokan Anandarajan. (1996). Auditor's View on the Type of Audit Report Issued to Entities with Going Concern Uncertainties. Accounting Horizons, 10 (2): 51-72.

Lee, P., W. J., dan Asokan Anandarajan. (2005). Going Concern Report Modeling: A Study Of Factors Influencing The Auditor's Decision. Journal of Forensic Accounting, 6 (1): 55-76.

Louwers, Timothy J., Robert J.Ramsay, David H.Sinason, Jerry R.Strawser, dan Jay C.Thibodeau (2011). Auditing \& Assurance Service (Vol. 4). New York: McGraw-Hill.

Menon, Krishnagopal., dan Kenneth. B. Schwartz (1987). An Empirical Investigation of Audit Qualification Decisions In The Presence of Going Concern Uncertainties. Contemporary Accounting Research, 3 (2): 302-315.

Mutchler, Jane F. (1984). Auditor's Perceptions Of The Going Concern Opinion Decision. A Journal of Practice and Theory, 3(2): 17-30.

(1985). A Multyvariate Analysis Of The Auditor's Going Concern Opinion Decision. Journal of Accounting Research, 23(2): 668-682.

Nasser, A.T.A., Wahid, E.A., Nazri, N.S.F.S.M, Hudaib, M.2006. Auditor Client Realationship : The Case of Audit tenure and Auditor switching in Malaysia. Managerial Auditing Journal, Vol.21, No.7, P.724-737.

Platt Harlan, D dan Platt Marjorie B.2002. "Predicting Corporate Financial Distress: Reflections on Choice-Based Sample Bias.”Journal of Financial Service Profesional. Vol. 56, Hlm. 12-15.

Scott, William. R. (2014). Financial Accounting Theory (Vol. 7). Canada: Pearson Prentice Hall.

Sussanto, Herry., \& Nur Mettani Aquariza. (2012). Analisis Pengaruh Opini Audit Tahun Sebelumnya, Kualitas Auditor, Profitabilitas, Likuidtas, dan Solvabilitas Terhadap Pemberian Opini Going Concern Pada Perusahaan Consumer Goods Industry yang Terdaftar di Bursa Efek Indonesia. Proceeding PESAT (Psikologi, Ekonomi, Sastra, Arsitektur dan Teknik Sipil), 5: 493-503.

Tagesson, T., \& Ohman. P. (2015). "To be or not to be - auditors' ability to signal going concern problems". Journal of Accounting \& Organizational Change, Vol. 11, Iss 2, pp. 175-192

Venuti, Elizabeth K. (2007). The Going Concern Assumption Revisited: Assessing A Company's Future Viability. The CPA Journal, 74 (5): 40.

Wertheim, Paul \& Michael Robinson. 2011. Evidence On The Effect Of Financial Distress On Type II Audit Errors.The Journal of Applied Business Research -November/December 2011 Volume 27, Number 6. 